International Journal of English Literature and Social Sciences
Vol-6, Issue-3; May-Jun, 2021
Journal Home Page Available: https://ijels.com/
Journal DOI: $10.22161 /$ ijels
Peer-Reviewed Journal

\title{
De-ideologizing Colonial and Postcolonial Sri Lanka: Family Tales and Historical Revisitation in Michael Ondaatje's Memoir Running in the Family
}

\author{
Hatem Ben Jemia
}

Department of English, Faculty of Arts and Humanities, University of Manouba, Tunisia

Received: 11 Feb 2021; Received in revised form: 20 Mar 2021; Accepted: 21 Apr 2021; Available online: 11 May 2021 (C2021 The Author(s). Published by Infogain Publication. This is an open access article under the CC BY license (https://creativecommons.org/licenses/by/4.0/).

\begin{abstract}
Recent theories of history have engendered large conceptual reviews at the level of historical representation, which has created gradual ruptures with the traditional perception of national history and its inherent assumptions of unity, They have produced profound epistemological shifts in the modes of national historical writings in postcolonial literatures These emerging writings celebrate productive elaborations of counter-hegemonic historical narratives, which break with the reductionist historical assumptions premised in dominant nationalist historiographies. By revisiting the national past through the trope of communal memory, and by exposing the obscured diversities of national experiences, contemporary minority writings have engaged in the task of interrogating the putative authority of official memory and historical documents by divulging the discursive erasure of representational differences characterizing the dominant nationalist historical narratives. In this context, postcolonial diasporic autobiographies have been offering dynamic sites of contestation whereby the authority of official history is undermined by competing narratives. Diasporic postcolonial autobiographical writings, for instance, have suggested productive literary spaces where unauthorized biographies of the nation have been introduced and subversive counter-narratives have been elaborated. It is within the context of South Asian re-configurations of representational praxis that I will locate my paper. The latter seeks to address the question of historical representation vis-à-vis nationalist discursive hegemony in postcolonial Sri Lanka, and to explore the narrative strategies deployed to disclose the flagrant injustices underlying the mainstream version of the colonial Sri Lankan history purveyed by nationalist ideologies evidenced in Michael Ondaatje's memoir Running in the Family.
\end{abstract}

Keywords-Communal memory, Counter-narrative, Family tales, Historical revisitation, Myth.

\section{INTRODUCTION}

Since the last quarter of the 20th century, the monolithic representations of the colonial and postcolonial national histories underlying the foundational nationalist narratives have been increasingly superseded by less static orientations that have toppled down dominant normative visions and its underlying cluster of essentializing assumptions. Influenced by the current representational upheavals in the arena of literature, the new waves of fictional and autobiographical writings introduced by second and third-generations postcolonial writers have significantly contributed to the elaboration of the counterhegemonic project of expanding the conventionallyestablished narrative of national history beyond the narrow rhetoric of anti-colonial nationalism and its intrinsic homogenizing and exclusionary paradigms, and reshaping it.

In the face of the totalizing impetuses underlying the official historical narratives of colonial and postcolonial Sri Lanka that largely impair the representational potential of non-official communal histories and jeopardize its limitless narrative signification, Michael Ondaatje 
celebrates, in his fictionalized memoir Running in the Family, the potential diversity characterizing repressed and marginalized communal narratives of Sri Lanka's biography. He suggests a non-conformist representation of the past that transcends the factual dimension of the classical autobiographical writings to carry a subversive impulse by disrupting the narrative unity and coherence. Thus, the writing of the past, in Ondaatje's memoir, involves a constant process of redefinition where teleological closures are replaced by apertures and where absolutist final conclusions are erased in favour of open endings.

The Sri Lankan Canadian postcolonial writer Michael Ondaatje exhibits a mindfulness of the fact that the institutionalized pejorative view and the discriminatory attitude towards the Sri Lankan minority groups have been firmly established and obviously reflected in the mainstream historical narratives of colonial and postcolonial Sri Lanka. His biography of colonial and postcolonial Sri Lanka, therefore, carries a critical stance towards dominant exclusionary representational paradigms. Ondaatje does not seek to reach an absolute historical truth and to entrench a certain power structure but rather to interrogate any discursively entrenched power structure by demystifying the inevitable constructedness of any historical discourse, and by unsettling the supposedly natural hierarchies of national narratives through the process of representational subversion. The latter is clearly conveyed in the creative narrative approach of portraying experiences of the past in Michael Ondaatje's fictionalized memoir Running in the Family.

Indeed, the representation of colonial and postcolonial Sri Lanka in Running in the Family surprisingly glosses over important national concerns, and clearly breaks with traditional representational paradigms premised in national mainstream historical narratives. The fictionalized depiction of the Sri Lankan past in involves shifting perspectives, which, unlike predominant narratives, carries no traces of narrative engagement in nationalist ideology. Rather than reiterating the so-called grand narratives of the nation, the author diverts the reader's attentions away from the major stories of anti-colonial heroism that are enshrined in the referential foundational historical texts and put in the forefront, and invites him to discover and illuminate other unexplored or little-explored aspects of Sri the life in the past along with sidelined contesting narratives, and to develop deeper critical insights on them, which will enable him to read the biography of Sri Lanka through new lenses..

This research article is a modest attempt to examine the counter-hegemonic motives underlying Ondaatje's historical representation of colonial and postcolonial Sri
Lanka. It seeks to explain how his autobiographical revisitation of the history of colonial and postcolonial Sri Lanka through the standpoint of his Burgher's cultural background and the communal memory of his ancestors potentially contributes to redefining the established borders of national historical narratives by throwing lights into its multiple yet repressed representational perspectives and suggesting alternative narrative approaches. The first section of this article will delve into subversive potential of introducing family tales and myths borrowed from the unofficial communal memory in the historical narrative of colonial and postcolonial Sri Lanka. The second section will cope with the fictionalization of history and the role of recalling and celebrating obscured past narratives in deideologizing the biography of Sri Lanka. It will explain how the author's fictionalized autobiographical writing largely consists in unearthing, celebrating, and reworking aspects of past experience and nationhood that have been easily devalued, denied, or dismissed in dominant ideologically-oriented historical narratives.

\section{DE-ESSENTIALIZING THE BIOGRAPHY OF COLONIAL AND POSTCOLONIAL SRI LANKA}

By constructing his historical narrative, Ondaatje does not search for merely replicating the grand narratives of the Sri Lankan history as much as he looked for retrieving and highlighting overshadowed unauthorized ones. His representation involves a productive contestation of a dominant historical narrative rather than a mere reproduction of its paradigms and assumptions. Veering away from the unilateral and ideologically oriented accounts of the past, Ondaatje throws lights on unexplored experiences, hidden aspects of the Sri Lankan daily lives, and communal cultural performances in the past that constitute a substantial element in national collective memory. Otherwise, Ondaatje's counter-narrative aims at expanding the borders of historical representation and gestures towards offering new tributaries for reading the national colonial and postcolonial past. His narrative reconstruction of colonial and postcolonial biography of his native nation implies the process of widening the historical imagery and enabling it to break free of the grip of ideology by transgressing its narrow representational paradigms and undoing their pertaining spiritless narrative demeanours.

In addition to his affiliation to a minority group, Ondaatje's diasporic lenses allow him to develop deeper insights into the question of national representation and to reconsider the legitimacy of the narrative uniformity purveyed by the hegemonic nationalist elite. While the 
latter almost absolutely refers to official factual reporting and often relies on centralized perspectives to mediate against undesired forgotten stories, Ondaatje largely evokes, in his quest of the past, non-official and nonfactual elements. Azade Seyhan (2001) posits that diasporic autobiographies:

problematize the issue of representation at many levels and highlight the relational character through the use of multiple narrators -parents, ancestors [...] and narrative genres such as myths, legends, criticism, literary fiction ,intertexts, or anecdotes". These narrative conventions contest and relativize representational authority. (p.95)

Unlike official nationalist historiography, which reduces national experience and imprisons its narrative within the anti-colonial frame, the representation of colonial Sri Lanka in Running in the Family revalorizes the multiplicity of national representation and foregrounds the national subjects' daily lives and experiences with its tiniest details..

Ondaatje's position as a Sri Lankan migrant having European origins and issuing from an upper class family as well as his fervent desire to reconnect with his lost Burgher's cultural identity significantly shape his narrative. Throughout the memoir, he glosses over some details that may have an extreme significance to most Sri Lankans and focuses on some others that may seem trivial to most Sri Lankans but very significant to him. Rather than exploring common political and social issues, he exhibits a particular concern with evoking national popular culture, and more specifically with celebrating the Burgher's cultural patrimony to which his parents were emotionally attached. Thus, the illumination of the systematically obliterated cultural memory provides "a counterforce to manufactured and monolithic memory" (Hartman, as cited in Seyhan, 2001, 39). While popular culture was often hailed as the warehouse of inherited significant myths and legends (which record ancestors' glories and consecrate the set of moral values enshrined by the colonized indigenous people) played a pivotal role in thwarting the obliterating effects implied in the colonial discursive hegemony, this popular culture was recalled in Ondaatje's narrative for its same subversive potential ,but also for different objectives that lie beyond the limits of classical ant-colonial concerns.

The author's celebration of shrouded aspects of the Sri Lankan popular culture is clearly evidenced throughout the text as a central subversive strategy aiming at elaborating counter-hegemonic national representations. He devotes, for example, a whole chapter (entitled "Tongue") to the myth of Thalagoya's tongue. Recalling such mythical narratives allows him to genuinely situate himself in the Sri Lankan cultural context and to get closer to his family's exotic life. The recollection of a humorous anecdote about his uncle Noel who was forced to eat thalagoya tongue even though he got very sick and almost died, gives us not only an insight into the eccentric traditions and myths of Sri Lankan Burghers but also a further insight into the symbolic character of Lalla who embraced these odd religious practices and who impacts the lives of his parents.

The recovery of national culture through an emotional recalling of the prototypical character of Lalla and the significant Thalagoya popular ritual offers to the author a means of coming to terms with his family's past but also of grasping the particularities of his communal cultural memory, and re-experiencing the fantasy that characterizes and valorises the Burgher's culture. When narrating their native nation, minority writers often place great value on magical folktales of their popular culture. These folktales represent a deeply symbolic and evocative cultural element, which provides them with an opportunity to develop a deeper insight into their experience in such a nation and in taking part in the construction of national narratives. In this context, Jason Dittmer (2010) admits that : "[p]opular culture can be understood as one of the main avenues through which narratives of nation are produced, and national subjects perform those narratives through their repeated consumption of that popular culture"(p.79). The insertion of elements of popular culture in Running in the Family is deeply embedded in the process of performing national narratives beyond the master narratives imbricated in official historiography.

In his memoir, Ondaatje does not play the role of the engaged historian who offers a purely realistic account of the past, but instead he achieves a rupture with the conventional historical writing by suggesting an emotional representation and a fictionalized rendition of it. Rather than sticking to factual assumptions encapsulated in the official history of colonial and postcolonial Sri Lanka, his gathered accounts of the past largely refer to popular imaginaries. Marc Colavincenzo (2003) notices that:

[t]he book repeatedly returns to the notions of exaggeration, tall tales, legend, and myth, and rather than discounts these elements as unreliable or untrustworthy, the writer both place them alongside reliable history as a valid mode of knowledge and also develops them further, inserting both a private and cultural in its public and private depictions of his parents. (p.155)

The reader is exposed, throughout the text, to a plethora of fragmented and mythical narratives that transcends the 
accuracy of facts and takes him to a subjective world of imagination and fantasy that is beyond the scope of official recording.

The interplay of facts and myths in Ondaatje's narratives of the past adds more consistency to national historical narratives as it imbues it with powerful imaginative elements, which genuinely express popular consciousness. In this context, Wilhelm Wundt (2006) posits that "[t]he historical interpretation of myths and commingling of mythical elements with real history are of the greatest significance for their preservation in the popular consciousness" (p.92). The mythical folktales imply an extreme representative significance, as they constitute the repository of national popular memory. The latter plays a key role in the subversion of claims of authority associated to the official memory. Although, it should be acknowledged that the strict boundaries between official and popular memory are actually not absolute, a general differentiation is still possible. Valerie Yow (2005) suggests a differentiation between the two terms. She writes:

An official memory is a version advanced by a group or person in a position of officially sanctioned power, A popular memory (sometimes referred to as vernacular memory) is a version held by a group of people who do not necessarily possess power -except cultural power as songwriters, storytellers, poets, speakers - but who have shared an experience. (p.54)

Yow (2005) concludes later that popular memory is "a counter-memory" as "it is different from official memory and challenges it (p.54). In this regard, the reliance on popular memory in Ondaatje's memoir carries clear subversive impulses as myths and family tales function as counter-narratives that withstand the authority of official ones.

In many interviews, Ondaatje does not hide his concern with re-exploring popular cultural horizons in the narratives of the past at the expense of historical accuracy. The large reference to popular memory underpins an implicit challenge to the factual authority of official memory but also it presents a challenge to the entire system of historical representation. He acknowledges, moreover, the imaginative dimension of popular memory and asserts that people have unclear memories and rich imagination, which undermine the reliability of information concerning the past. He (2011) recognizes, for instance, that "[p]eople's memories about Gasanawa [a notorious Rubber estate transformed later into an arena in which an annual party was organized], even today, are "mythic" (,p.28). The popular inclination towards the mystification of memories and the resultant fictionalization of the past contradict nationalist representational approaches and their inherent classical assumptions about the historical representation that are grounded on notions of accuracy, objectivity, and closure.

The mythicization of history in Running in the Family conveys the author's concern with exploring popular consciousness of the past and the cultural performances of its events which official recordings often display. Despite their surreal nature, Ondaatje insists on the fact that the inherited mythical stories are more genuine and more expressive. Indeed, beyond the literal understanding of their events, these stories imply profound significations and greater representational value since they embody the popular consciousness of its narrators and purveyors. Denman Collin (as cited in Dittmer, 2010), argues that "popular interpretations of historical events are often much more significant than events themselves. In other words, later mythical elucidations have more impact than on what actually happened"(p.20). While Ondaatje sought, initially, to uncover the past through documental materials, the extreme expressiveness and the enticing narration of the mythical stories divert his attention away from facts. Confronting the danger of presenting inaccurate memories as facts and idealized recollections as evidences, and determined to see beyond what may be merely the appearance of truth, Ondaatje decides to take part in the popular mystification of the past by creating mythical assumptions about the past that may even record the more intense expressions of realities of his time and of his own people.

The truth-value of Ondaatje's narrative is premised in oral history, perceptions and imaginary experience - the last of these suggesting a kind of magical realism. Although Ondaatje's starts his quest of the Burgher's past by adopting classical scientific approaches of research such as factual investigations as any other traditional historians, the reader notices, as the narratives progresses, a gradual deviation from the forensic methodology and a surprising immersion into the realm of imagination. In fact, the author's principal discursive technique in moulding his historical narrative was, first; the gathering of facts from both official and communal memory and, when the facts fail to speak, turning to myth to give explanations and fill in the gaps. For the author, the deeper grasping of the past is possible first through experiencing it directly and intensely through his emotions like his ancestors did before, mainly with the paucity of credible historical resources. Rather than books, the body and the innate life becomes the locus of history. He (2011) writes: "[m]y body must remember everything, the brief insect bite, smell of wet fruit, the slow snail light, rain, and 
underneath the hint of colours."'(p.184). For the author, a real reconnection with the past comes not through the exposure to official facts in historical annals but rather through genuinely experiencing an emotional and imaginative reconciliation with the simplest and tiniest details from daily life. Being a substantial element constituting daily life in the past; myths and family stories in Running in the Family highlight the power of the story to be sincere, comprehensive, and evocative. It can be formidably powerful with the very elements of its inauthenticity. Even though myths lack a clear historical background and scientific validity and shade into the supernatural, they are potentially expressive since they are produced in the minds of ordinary people unlike historical facts that are institutionally and discursively imposed and mostly inexpressive of the popular consciousness of history. When recreating the past, Ondaatje seeks to push his family's history towards fiction, to evade the superficiality and the monotonous mechanical aspect of historical narration, and to imbue his representation with a deep and powerful meaning where the real negotiates with the magic. In this context, George Eliott Clarke (1991) defines myth as "a story based on tradition or legend, which has a deep symbolic meaning". He explains that "a] myth 'conveys a truth' to those who tell it and hear it, rather than necessarily recording a true event"'(par 9-10). Stressing the contradictory nature of the myth, Clarke (1991) adds that:

[m]yth achieves its greatness when its most incredible elements seem authentic and believable [...].Yet myth is also characterized by ambiguity and amorality, it resists definition even as it defines. It exists in a tension of utterance and silence, motion and stillness, reality and dream never quite being the one without the other. Its clarity is obfuscation and its obfuscation clarity. (para.. 11)

Unlike real stories, mythical ones derive their lure from their rich symbolic significations and their endless ability to give more meanings to the past as their highly evocative images allow for vivid and spiritual reconnections with events and people in the past.

The large signifying potential inherent in these stories, and its influence on the culture in which they developed, are the major reasons behind their survival as long as they do - sometimes for thousands of years. Their importance lies also in their ability to embrace and to fuse diverse dimensions of the past and their amenability to absorb at once individual and communal experiences in the past. Clark adds that " [b]eing individual and communal, myth incorporates all things". In the face of totalizing visions of the past that characterize nationalist reading of the Sri
Lankan past, and which underpin official historical narratives, Ondaatje tends to mythologize popular imagery of the national history as a way of revamping and reinvigorating national past narrative after years of stagnation and even degeneration.

Ondaatje who asserts that "in Sri Lanka a well told lie is worth a thousand facts" strongly believes in the formidable subversive potential underlying popular stories (p.189). He agrees, hence, with John Thorn who underscores the great importance of myth in any historical investigation and exploration as he (as cited in Klein, 1997) posits that "[h]istorians have an obligation to embrace myth as the people's history" (p.4). Ondaatje celebrates a perception of history that achieves an epistemological rupture with the traditional one. In his view, myths are more circulating among members of society than facts, and they are more impactful on their understanding of history. Fictional narratives discard whatever lies beyond the narrow circle of facts. Ondaatje's perception of history that is evidently mirrored in his narrative is premised on the assumption that the historical narrative which is established and everlastingly entrenched in the collective memory of the nation is, actually, not the factual one but rather the imagined. The latter is the one whereby society's perceptions are based

The author's disengagement with conventional standards and his belief in the importance of non-official popular interpretations and reconfigurations of the past through the evocation of myths is evidently conveyed in his odd and unexpected representational orientations which flout ideological constraints. Ondaatje's large reliance on fantastical elements in reproducing the past is enhanced by a fervent desire to recollect his cultural roots, but also to have access to alternative non-ideological spaces of the national past to which he can genuinely identifies himself. More precisely, he wants to situate himself within the rich and highly evocative mythical dimension of the Burgher's culture in particular and the national culture in general. Dominique Tooher (2010) asserts, in this context, that Ondaatje's obvious straddling between fiction and autobiography can be considered as "[a]n attempt to come to terms with a past that is both personal and cultural" (p.14). Ondaatje seeks to bring back, not only past events, but further the lost elements of the colonial and postcolonial Sri Lankan culture that help him to recover its aspects and significations in the quest for a lost identity. Nevertheless, the author concern with the cultural aspect of the Burgher's past does not imply a total exclusion of political events marking the history of colonial and postcolonial Sri Lanka.

In fact, the autobiographical narrative in Running in the Family, illustrates many historical events taking place in 
the colonial and postcolonial period such as the Easter Sunday Raid. This event is not directly introduced to the reader but vicariously through the means of anecdotes and mythical tales produced and inherited among the Burgher's minority over generations. The mythical rendition of this historical event has an extreme significance for the author as well as for all Sri Lankan Burghers who are searching for genuine reconnection with their cultural memory in the face of institutionalized cultural erasure. In contrast with the strictly ideological reading of the Japanese raid on Sri Lanka (including the incident of the train bombing) in nationalist historiography, which persistently tends to recall the dichotomy of colonizer/colonized by establishing facile division between collaborators and victims, Ondaatje's evocations of the story complicate this simplified nationalist reading. In this incident, the role of Mervyn, (Ondaatje's father who definitely stands for the colonizer Burgher in the official story and accordingly he is in a way or another one of the collaborators of the bombing) is quite confusing.

Exposed to contradictory details, the reader cannot draw definite conclusions about the reality of Mervyn's implication in the incident. In addition, the anecdotal and mythical-like aspect of the story works to stultify the alleged objectivity of nationalist treatment of colonial and postcolonial events as it invites the reader to get rid of the teleology of official history and to get exposed to alternative perspectives, and accordingly draw multiple conclusions and interpretations. I believe that the father's enigmatic relationship with the bombing incident is an allegory for the Burghers' conscious ambivalence translated into an undecided attitude and a mysterious relationship with colonialism. Such ambivalence stresses the hybrid political and cultural background which resists absolute identifications anchored to the Burghers and embedded in the nationalist historical representations.

Through imbuing the historical events with communal myths and familial sagas, Ondaatje explores and foregrounds the tenuous boundaries between national historical experience one the one side and family's experience one the other side in ways that complicate national historical representation and "disorients," in Bhabha's (1994) words, any simple division between the national and the domestic life often embodied in nationalist historiography (p.14). This disorientation opens wider doors for shaking commonly espoused visions of national history and allowing the memoir to represent access to counter-histories through non-classical representational models such as cultural memory, dreams, oral traditions, and other means beyond the frame of official historiography. By and large, the emerging contemporary writings in general and memoirs in particular are looking for new narrative patterns which horizon towards recasting alternative histories beyond the narrow confines of the ideologically-defined frames.

Influenced by the cultural background of his family, which valorises and celebrates surreal fantastic elements, Ondaatje carries out an imaginative act of journeying and writing, undermining any possibility of credibility and authenticity. He tends to mythologize facts of his private story and to construct his family's history around myths, rumours, and gossips; triggering imagination, giving a mythical dimension of the past by imbuing it with a sense of magic, and making the historical narrative not only fictionalized but also reinvented and reshaped. Throughout the text, Ondaatje fantasizes his family's life but also deaths (such as his grandmother mysterious murder which will be examined later). He seeks through mythical evocation to fill the missing gaps of official history. However, this filling is never limited. It implies an ongoing and endless process of interpretations and significations. Through the very act of retelling tales about his family, the narrator is reconciling with the past of his Burgher's community. More importantly, he is taking part in the unearthing of substantial elements of national narratives.

Ondaatje's inclination towards re-telling mythical popular tales is evidenced since the beginning of the memoir. When he decided to recreates his father' image he sought to begin with factual truth. However, as he started writing, he moves outwardly to mythologize him. In the opening passage of the memoir, he imagines his father in a fantastic situation where he seems" chaotic, surrounded by dogs and all of them were screaming and barking into the tropical landscape "(Ondaatje, 2010, p.3). This surreal representation of the father stems from his mythological unconscious and translates his inner passion for a wild mythical life that he misses. This mythical life constitutes a part of the national cultural memory identity that he wishes to recover. What Ondaatje actually writes, therefore, is not an objective history as he uncovers it. It is the awakening of his consciousness to the implications of the fascinating realities that he discovers, and of the connections that he perceives as he contemplates the evidence before him. And it is this awakening that raises his historical consciousness and hence strengthens and confirms his cultural identity. Accordingly, Ondaatje is not concerned with offering a purely realistic identical portrayal of the characters but instead he seeks to suggest a problematic representation that arises from his emotional imagination where characters oscillate between fact and myth and between history and fiction. The mythologization of characters touches the domain of the 
imaginary, which allows Ondaatje to experience a deeper self-exploration that leads to a liberatory transgression of boundaries by transcending the confines of the rational scientific historical representation. The author, therefore, redefine and transcend the boundaries of historical writing by taking what is realistic and familiar and pushing its limits.

The non-factual nature of his representation is intriguing for it paradoxically adds a kind of authenticity to the narratives.. The significations of the mythical stories whether gathered from relatives or articulated in the writers' imagination functions as symbolic references through which the writer elucidates his own perception of the past and the nation, and whereby he underpins his counter-narratives. Moreover, this fantasized representation allows him also to add his voice to the versions of others about the past. Indeed, through the very act of retelling tales about his family, the narrator becomes the protagonist who participates in the cultural memory of the community and achieves, in some ways, a sense of belonging. Through the trope of magic and myth, Ondaatje throws himself into the realm of imagination and reexperience exotic aspects of his family's past representation that historical documents could not provide. He imagines, in one of his emotional recollections of his family's past, a fantastic story of his grandmother being swept away during a storm. He (2011) writes:

It was her last perfect journey. The new river in the street moved her right across the race course and park towards the bus station. As the light came up slowly she was being swirled fast 'floating' (as ever confident of surviving this too) alongside branches and leaves, the dawn starting to hit flamboyant trees as he slipped past them like a dark $\log$, shoes lost false breast lost. She was free as a fish. (110)

This fabulous story of Lalla's nebulous death is quite confusing for since it contradicts with the "natural causes" of her death mentioned earlier in the book (p.35). This contradiction further proves that Ondaatje deliberately conflates elements of incredibility and inauthenticity in his narratives in contrast with scientific standards of historical inquiry. While classical biographies in nationalist narratives are characterized by their factual elements and endowed with a high level of 'credibility', Lalla's one carries irreconcilable elements of credibility and incredibility. Hence, mythical stories become more potent and alluring than historical facts because they can narrate human experiences with their endemic contradictions and peculiarities, and even with its unreasonableness. Through the story of Lalla, Ondaatje seems to justify the postmodern interpretations of his textual practices.
Multiple narrative voices provide the reader with different perspectives, none of which can claim to offer a supreme truth.

Furthermore, the mystification of Lalla in Ondaatje's narratives of the past is a celebration of the Burgher's woman's image, which was doubly marginalized as being a female and a colonizer. According to Joanne Saul, the captivating and controversial story of Lalla in Ondaatje's memoir works as a counter-hegemonic strategy to contest patriarchal historical representation as it challenges the predominant andro-centric historical narratives which relentlessly amplify male heroism and systematically reduce female presence in the narratives of major national stories. (Saul, 2006, p.43). Further, the mystification of the character of Lalla carries other obvious subversive motives. Indeed, the life and the death of Ondaatje's grandmother are too mysterious to the extent that they captivate the Burghers' attention and become entrenched in their collective memory (Saul, 2006, p.49). Though she never took part in anti-colonial activism and consequently never had been recorded in official memory among national heroes, the biography of Lalla continues to mark the national popular memory. Marc Colavincenzo (2003) suggests that:

Ondaatje is working with historical figures who, embedded in their own histories and the history of their social class, have achieved legendary status and notoriety. This is seen particularly in the way Ondaatje deals with his father and grandmother. In incorporating the tales and rumours surrounding these figures, Ondaatje uses the possibility of fiction to enrich the texture. (p.155)

Through the fantastic story of Lalla, the reader can notice the author's deconstructionist approaches that are premised on the textual subversion of the official stories of heroism and the questioning of their absolute supremacy and authority over the communal one. Indeed, national events, in anti-colonial nationalist historical narratives usurp the private, personal experience which occurs within the limited family sphere. Often defined as secondary and trivial stories, which are definitely subordinate to public, large-scale national narratives, these family stories can never exist on a par with them despite their intrinsic representational value. Indeed, nationalist historians always seek to establish a rigid division between the private and the public sphere by keeping the family's influence absolutely separate from and subordinate to the national, thereby creating a situation where the family and nation exist both in opposition to one another and where any valuable narratives of national history should necessarily get rid of family stories' influence. In contrast, the narrative, in Ondaatje's memoir, constantly blurs the 
boundaries between the public and private life and dismantles the supposed supremacy of the national over the familial. By and large, Ondaatje's narrative revisitation of his grandmother story as part of his family and community stories falls within his deconstructionist representational project, which rethinks and goes beyond nationalist exclusionary paradigms. Erin Haddad-Null 2013)l posits that:

[t]he family histories offer a means for representing access to counter-histories. Those historical experiences often occluded or excised from official accounts of history. These counterhistories typically emerge from a need to understand the way particular forms of nationalism suppress or elide certain experiences. (p..24).

Moreover, the regenerative potential of mythical stories about Lalla and other figures liberates the national past from certainties and closures. Unlike facts, myth 'prefers to work with poor, incomplete images' (Tallack. 1995, p.39). The gaps left by myths offer a productive space of constant interpretations and imaginations, and hence give more immediacy and freshness .to past narratives. Along with the character of Lalla, many characters in Running in the Family are transformed into myths. They transgress their real natural aspect to be cloaked in ambiguity and immersed in a magical surreal realm, which complicates the reader's identification with them. In this context, Will Verhoeven (1992) maintains that

[a]gain and again persons (or their identities) get lost in Ondaatje's stories-lost in legend, lost in the bush, lost in the past, lost in history, lost in memory, lost in myth - and in each case people go after them in order to recover them, to remember them or to recreate them.(p.181-182)

Marc Colavincenzo (2003) notices, in the same context, that:. "[i]n Running in the Family, the inclusion and expansion of the well told lies of tall tales, legend, and myth which already surround his family history push that history towards myth" (p.156). The endemic mysteriousness of characters and stories in Running in the Family makes Ondaatje's version of the Sri Lankan colonial and postcolonial past more intriguing. In fact, the reader never feels the sense of stability offered in classical historical narratives. Lost in the maze of oddity and contradictions, he has no alternative but to take part in the process of reconstructing the past out of mythical but also fragmented images. Ondaatje's problematization and mythicization of his family's past is subsumed under his fervent desire to reconnect with his origins and to position himself within his Sri Lankan Burgher's history. Further, in contrast with nationalist criticism that contends that Ondaatje suggests a trifling narrative that consists in an almost loquacious depiction of the Burghers' past experience, his narrative, thanks to the added mythical lure, is fraught with grandiose glory and heroic adventure which are worth to be celebrated and embedded in the narrative of national memory.

\section{DE- IDEOLOGIZING THE HISTORCAL REPRESENTATION}

The historical narrative in Ondaatje's memoir Running in the Family largely revolves around the process reexploring the unofficial communal memory not the official one. Its construction consists in evoking Burghers minority' past experiences which were inherited over generations and illustrating the host of tales and myths that constitute a substantial part of it. By the frequent recourse to mythical stories and family tales, Ondaatje's narrative seeks to open up unexplored realms of national experiences, to celebrate their diversity, and ultimately to dispel the myth of homogeneity anchored to official nationalist representation of colonial Sri Lanka. The author's obsessive tendency to mythicize colonial and postcolonial Sri Lanka surprised readers and critics as well as it results in a rupture with the mainstream narratives defined by the nationalist enterprise. The unconventionality of his narrative style evidenced in his insouciance with the carefully established criteria of credibility sparked heated debate amongst the Sri Lankan literary critics.

Many literary critics such as Arun Mukherjee and Chelva Kanganyakam contend that Ondaatje's depiction of Sri Lanka's colonial history in his memoir is unfamiliar and problematic since it surprisingly stultifies the engaged anti-colonial nationalist reading, which was occupying the forefront of literary concerns after independence. In fact, issues that topped the national debate during the colonial epoch and the post-independence period are almost played out within the limited context of his Burgher family's private life. The narrative, though historically covers the colonial and postcolonial period, was unexpectedly beyond ant- colonial concerns since it neither addresses a direct and a concrete engagement with the legacy of colonial rule and an explicit critique of its oppressive discriminatory practices nor does it address the major destabilizing events marking the turbulent post-independence period.

Throughout the text, major large-scale national events are, as mentioned earlier, almost glossed over by the author and even the few hints about the colonial and postcolonial political and social agitations are partly linked to his family past. Except some occasional references to 
the colonial presence in Sri Lanka, the representation mostly ignores the long historical role the British Empire played in the formation of the Sri Lankan nation and overlooks the injustices and ravages of colonialism. The memoir consists largely of fragmented stories about the narrator's aristocratic family, accounts of their daily activities, lifestyles, rituals, and traditions, etc ..., along with scattered reflections on these stories. They are meticulously depicted in the narratives because they have a direct relation with the author's extravagant life. The aspects of extravagance figure saliently in the memoir and the author leaves the reader with the impression that Sri Lankans enjoyed a high European-like standard of living and never experienced colonization and its injustices.

Apart from colonization, the significant national events tainting post-independence Sri Lanka which are considered as principal in national postcolonial history are merely explored or completely ignored within the narratives. Indeed, Ondaatje uses the old name Ceylon to refer to his native nation even though it has been officially named as Sri Lanka since 1971. The use of Ceylon in the text rather than Sri Lanka conveys the self-consciousness of the author's representation. Because much of his narrative takes place during the pre-independence era, Ondaatje is mostly writing about Ceylon .He never lived in the country when it was named Sri Lanka. Through the use of the old name of his homeland, Ondaatje prefers to keep a distance from the mainstream and ideologically loaded historical discourse by situating the Sri Lankan culture and history into the subjective realm. In his highly self-reflexive narratives, Ondaatje bucks the critics and the readers' expectations by foregrounding the subjectivity of his representation and exhibiting a lack of concern about official historical narratives shaped by the nationalist ideology. He brings the Sri Lankan (or Ceylonese) colonial and postcolonial past into his mind and emotions, and translates it into his own words through non-conventional representations.

His deep immersion into the mythical world of communal sphere and provoked the politically engaged critics. Indeed, specific houses, luxurious buildings, vast Edenic places, and festive events are, for these critics, completely irrelevant to the nation's gloomy reality at that period marked by the continuous agitations and prevalent misery. .In this context, Daniel Coleman highlights the superficiality of Ondaatje's treatment of political problems in colonial and postcolonial Sri Lanka which evades direct treatment of the legacy of the colonial enterprise.. He (1998) maintains that:

Ondaatje does mention in passing the student insurgency of 1971, but he makes no attempt to address its significance in Sri Lanka's history. He does not explain that young Sri Lankans tried to force the postcolonial government to redistribute the land more equitably and to offer more opportunities to the poor; nor does he divulge his own plantation-owning family's comprador relation to political power during that turbulent time .(p.122)

The narrative of colonial Sri Lanka does not offer concrete historical evidences and consistent information about the political tension that marked the post-independence era and its immediate impact on postcolonial Sri Lankan society. In contrast, when representing Sri Lankan contemporary history, Ondaatje exhibits a particular preoccupation with the emotional evocation of his family's past and ultimately with the quest for his own origins rather than with celebrating the historical momentum of anti-colonial struggle and exploring the vagaries of postindependence era.

Most Sri Lankan critics suggest that the book is ahistorical. According to them, its narrative is out of context. The representation of colonial and postcolonial Sri Lanka suggested in the memoir, according to them, starkly lack representational significance as it is emotionally focused on the local familial context that it does not situate the author's story within the wider framework of national colonial and postcolonial history. In other words, the autobiographical text was blamed for falling to address the political and social realities in colonial and postcolonial Sri Lanka. Amidst the criticisms of the book is that of Arun Mukherjee .He suggests that the memoir flagrantly lacks political commitment as it does not draw attention, for instance, to the bloody ethnic-based confrontations between the Sinhalese and the Tamils in the mid 1950's, which are one of the most traumatic events in Sri Lankan postcolonial history. Paradoxically, events of minor importance are extensively mentioned. Arun Mukherjee expresses his extreme disappointment with Ondaatje's obsolete, misleading, and inaccurate narratives of Sri Lankan contemporary history. Through the lens of an engaged nationalist critic, he harshly criticizes what he (1994) considers as "Ondaatje's unwillingness or inability to place his family in a network of social relationships" and complains that the book is drenched in the local context and gives few indications about Ondaatje's social Sri Lankan background (p.122).

More importantly, Mukherjee blames Ondaatje's on what he believes as the obvious lack of anti-colonial commitment. He (1994) considers that the author:

does not get drawn into the act of living, which involves the need to deal with the burning issues of his time such as poverty, injustice, 
exploitation, racism, sexism, and he does not write about other human beings unless they appear to be artists -or members of his own family. (p.99)

The narrative, according to Mukherjee, draws a very narrow portrait and even an elusive insignificant image of colonial and post-independence Sri Lanka. He considers that this image of the past is almost focused on upper class's extravagant life that is strongly tied to the author's aristocratic surroundings and does not offer an audacious critique of the negative colonial legacy or, as he (1994) puts it, "the sordid realities created by centuries of colonial exploitation"(p.40). Mukherjee condemns in the strongest terms, Ondaatje for what he sees as unrealistic and extremely exoticized portrayal of the nation while he is supposed to delve into the real problems threatening the unity of the nation when he (1994) contends that "[w]e are repeatedly given paradisiacal images of flower gardens, paddy fields, tea estates and forest reserves, but no contemporary picture of Sri Lanka - which Ondaatje calls Ceylon - emerges" (p.121). The pervasive images of luxury and the romantic, mythical-like and exotic depiction of the daily life are, for Mukherjee, poorly representative if not irrelevant to the miserable reality of colonial and postcolonial Sri Lanka. Mukherjee (1988) goes even further and posits that : "Ondaatje takes sides with the colonizer"(p.121). He assumes according to him, the role of the colonial orientalist because he exhibits no concern with the real preoccupations of indigenous people, but also because he extols what he called the Burghers' disgraceful past.

Chelva Kanaganayakam shares Mukherjee's position and suggests that Ondaatje's attempts at representing colonial and post-independence Sri Lanka are an outright failure. According to him, the author's dismissive attitude mirrored in his shallow representation of Sri Lankan political reality and his reluctance to "to be drawn into the issues that surface in any serious discussion of the country" has further demonstrated his disloyalty to the national project in Sri Lanka and argues that "the work's weakness lies in its refusal to participate actively in the referential, in its reluctance to condemn or praise, in foregrounding the narrative at the expense of the national"(as in Saul, 2006, 45). Inasmuch national belonging in the narratives of anti -colonial nationalism is determined by the extent of involvement to the anticolonial struggle and the national nation-building agenda, the nationalist critics went further to call into question Ondaatje's belonging and loyalty to Sri Lanka.

Kanaganyakam (as cited in Saul, 2006) carries on his critique of the insignificance of the historical representation in Running in the Family, and considers that the author, through his insouciance, with his nation's colonial and postcolonial past, he implicitly disavow the glorious sacrifices of Sri Lankan people over their colonial and postcolonial history and "abandons a wonderful opportunity to assert a much needed sense of belonging"(p.45). Because of the sentimentally focused and one-dimensional portrayal of his homeland which disregards the sufferings of colonial experience and the horrors of post-independence civil war, Ondaatje fails, according to him, to assert his belonging to the very nation he is representing. Kanaganayakam infers that Ondaatje's blindness to historical realties proves his colonial lineage and colonialist affinity. The unfavourable position and non-supportive stance towards Ondaatje's autobiographical representation reflected a critical trend that assumes the supremacy of well-defined and carefully established norms and paradigms of writing about colonial and postcolonial Sri Lanka.

Apart from the purely aesthetic measures, I believe that evaluating the representational quality of Ondaatje's representation of s history and assessing it in terms of specific criteria ascribed to it like the commitment to the nationalist agenda is completely erroneous. First, because anti colonial nationalism is, after all, a political ideology among many ideologies existing during colonial and postindependence era even though it is the most prominent one

- Second, Ideological commitment is never a credible criterion for determining good or poor representational value. Third, claims of inaccuracy ascribed to Ondaatje's narratives of the past have no foundation only if we consider that Ondaatje's memoir is a referential and politically engaged historical document in the pure sense of the word. That is not the case as in the acknowledgement section Ondaatje (2011) clearly puts it: "I must confess that this book [Running in the Family] is not history but a portrait or gesture" (p.176). The memoir is not a history in the sense that it does not endeavour to offer a referential historical knowledge for academics, but instead a personal self-reflexive and fictional literary narrative. Fourth, the claim that Ondaatje's narrative of colonial and postcolonial Sri Lanka is a failure in terms of representation seems preposterous. Conversely, Ondaatje's narratives offer new and important perspectives, which contribute significantly to expanding and enriching the national historical narratives. Rather than reformulating a single version of national history and reiterating the carefully established narrative approaches, Ondaatje illustrates, in his memoir, other hidden untold stories which were eclipsed and marginalized yet enough rooted in the collective memory of Sri Lankans, and reifies the polyvocality of the historical representation. 
While the suggested biography of colonial and postcolonial Sri Lanka in Running in the Family was criticized for the so-called excessive subjectivity and exaggerated mythicism as well as its alleged failure to address the political and social reality in Sri Lanka , I think that Ondaatje's memoir, despite its mythical dimension, does not lack a political commitment. Instead I find that the narratives transmit a powerful political message to the radical nationalist literary elite who pushed Sri Lanka to a vicious circle of ethnic-based discrimination and violence because of their narrow and essentializing historical assumptions, and their representational flaws. The memoir carries implicitly a deep critical revisitation of the dominant nationalist discourse as it implicitly challenges the exclusionary tendencies that result ultimately in a bloody civil war and an ongoing destructive ongoing political detritus. In my opinion, Ondaatje's focus on his personal experience and his family's tales does not involve a lack of national engagement. Rather, I think the author seeks to evade the classical political criticism in conventional postcolonial fictions that shed extensive light on the large -scale national experiences or the grand narratives at the expense of minor individual or communal ones. By rewriting the national history, from the Burghers' standpoint, Michael Ondaatje disrupts the unity and homogeneity of the national narratives and stresses their inescapable diversity and contingency. Through the trope of mythical family tales, he calls for a pluralistic multidimensional national representation, and throws into doubt the supremacy of the official foundational narrative of Sri Lankan colonial and postcolonial past embedded in the national literature, and challenges its authorial voice.

Ondaatje, like other second-and-third generation diasporic writers, raised more awareness towards the endemic problem of representation lurking in the majority of nationalist literary representation of national history. He understood that the deterioration of historical narratives is partly linked to the narrow perception of the nation, which fails to grasp the quintessential idea of difference and the inescapably narrative quality of historical representation. Fuelled by the desire to transcend the stifling dichotomy of colonizer Vs colonized which forces him towards a uniperpectival assumptions about the Sri Lankan history, Ondaatje seeks, through writing a new and mostly unknown version of colonial and postcolonial Sri Lanka, to pull the rug from under the hegemonic nationalist institutions. Writing about the past, in Ondaatje's view, is a genuine act, which goes beyond ideological considerations. In fact, Ondaatje's revisiting of national colonial and postcolonial past implies a journey across time and spaces through which he explores the depths of one's origins and one's own identity in the very details of family's life rather than a literary reproduction of the master narratives of decolonization and nation-building recurrently mentioned in the official historical annals and imposed as a criteria of a positive critical reception. He achieves a rupture with historical conventions and defiantly exhibits a total insouciance towards the politically correct shibboleths.

The author's obvious unconcern with the ongoing postindependence political instabilities and the resultant social agitations is due to his Burgher lineage and more specifically to the peculiar context in which he grew up. Indeed, Ondaatje belongs to an aristocratic family and community who are not much involved in the colonial and post-independence questions in Sri Lanka. When asked about the representation of his burgher's family in an interview with Linda Hutcheon he (as cited in Saul, 2006) asserts that:: "[h]ere I was writing about a group of people that seemed utterly separate in some ways from the world around them, unaware of what was going on around them politically or whatever" (p.46). The lack of political involvement and their isolation in their own world of magic tales and myth and altered their perception, and hence narratives of the past. The set of inherited tales and myths becomes a receptacle for their narratives and a vehicle whereby their historical consciousness has been formed.

Furthermore, Ondaatje's ties with his homeland are very tenuous since he left it when he was only twelve years old. His relationship to the past is in process which implies that he cannot have a full sense of connection and belonging. Aware of his historical severance from his nation, or more specifically, from the nation's official narratives, Ondaatje does not claim to produce a comprehensive and referential image of colonial and postcolonial Sri Lankan politics and society which meets with the ideological constraints . Rather, he is only seeking to draw a portrait of his family as a part of his country. In this regard, some critics have been more sympathetic to Ondaatje treatment of Sri Lankan colonial and postcolonial history, particularly in the light of the author's complex position as an aristocratic Burgher living outside Sri Lanka.

Daniel Coleman justifies the narrative rupture dominant past narratives in Running in the Family which deprecates the grand narratives of the anti-colonial ideology by what he suggests as "Ondaatje's lack of direct engagement with national politics' generated by the fact of 'his severance from everything Sri Lankan -including culture, history, and politics"(Daniel Coleman). By the expression 'severance from everything Sri Lankan', Coleman refers to the author's detachment and alienation from the mainstream national social, cultural, and political context. 
Ondaatje surprises his readers as he complicates historical writing through highlighting his distance from Sri Lanka's post- independence past as experienced by the majority of people and exploring the various factors that cut him from it. The deep reasons lying behind such severance are beyond the scope of this research paper. What matters here is the effect of such severance on the writer's perception of the national history. It goes without saying that living outside Sri Lanka for a long period does not only imply living outside the national space. It implies further a rupture with the mainstream official discourse. Being neither taught in national educational institutions nor exposed to national media reduces one's involvement in the nation's main political, social, and cultural challenges. This lack of direct involvement in the current national debates will certainly affect his perception of his native nation.

Furthermore, the fact of living outside the nation and belonging to a minority group under a typically nationalist regime perpetuates one's detachment from the fundamental narratives of the nation. In the case of Ondaatje, being both Burgher and diasporic with the resultant rupture from the predominant ideology complicates his sense of belonging since his own representation of the nation does not meet with established standards of accuracy and credibility. A priori the severance from the predominant narrative of the nation doesn't necessarily entails a total rupture with one's native nation as much as one can perform his national identity through his own narrative. However with the totalizing and exclusionary ideology of anti-colonial nationalism, a full adoption of the national foundational narratives is the major criterion for achieving a true national belonging. Indeed, Nationalists critics 'desire for a single official story led to the erasure of narrative multiplicity, thereby obscuring one of the features by which the Burghers narrative traditions differed from the dominant historical consciousness

In their obsessive quest for uniformity, anti-colonial nationalist ideologues imposed strict measures of factual accuracy and credibility according to which literary and cinematographic past narratives are accepted or rejected. It is important to note that popular mythical stories or folktales about the past were never welcomed as referential elements in writing the official history. Being perceived as a source of confusion, which hinders a rational teleological explanation of the past, and threatens the coherence of historical narrative, the cultural performances anchored to popular past narratives are often dismissed in the official historical documents (Hartman, 1994, p.33). In this context, Azade Seyhan (2001) observes that official grand narratives of the past are essentially monolithic narratives in which participants are subordinated to the rule of purely ideologically non-reflexive perspectives. He posits that "[t]he monologic authority of official history undermines the only active communal memory we have' which lives in poetry, legends, symbols, songs, and dances [oral cultural performances]" [emphasis added] (p.39). The formidable power of this communal cultural memory to enhance continuous interpretations and to reproduce multiple and regenerative narratives which thwart exclusionary ideological frames often exasperates nationalist ideologues who are obsessed with normalization and essentialization.

The deliberate marginalization of communal memory's narrative becomes even more radical when it comes to a minority group's one. Regarded as the bad remnants of colonization, the Burgher's communal memory was systematically rebuffed as being irrelevant with the national context and unworthy for recording and assimilation into the official national memory. Their miscellaneous experiences, despite their intrinsic cultural richness, went almost unnoticed in the bulk of national history books. Sri Lankan students grew almost unaware of the cultural aspects of colonial and postcolonial past since they are not exposed to national popular stories. Promoting forgetting in national schools has become an efficient strategy whereby the obliteration of communal memory is ensured. With the outbreak of ethnic based violence, the systematic erasure of narrative multiplicity has grown more and more radical to become one of the landmark policies of the successive nationalist governments. As a corollary, many parts of the marginal Burgher's 'past haven't really been explored.

Ondaatje mourns the loss of such past as he confesses that he (2011) "had slipped past a childhood [he] had ignored and not understood" (p.22) Since his departure from Sri Lanka he has been haunted by his father's memory and obsessed with understanding his mysterious life as well as unravelling the enigmatic circumstances of his tragic death. He realizes that such understandings are primordial in the process of recovering a lost and precious part of his identity. He realizes, further, that recovering his family stories and coming to term with his Burgher community's past during colonial and postcolonial period are central in his quest of the father. While he relentlessly sought, during his diasporic life outside his native nation, to compile facts and to learn more about his community's lives during that period through reading history books, he failed to get something important upon which he can draw pertinent conclusions due to the paucity of information about Burgher's life offered in such books. Being under the grip of nationalism, national history was extremely selective. Stories about ethnic marginal groups were almost completely erased from official historical 
documents in favour of the grand narrative of decolonization.

In his memoir, Ondaatje withstands unquestioned identifications with official narratives of nationality, which have underpinned the national official history. His problematic representation of Sri Lanka's colonial and national past demystifies the subtle and covert mechanisms of symbolic violence (which are the modus operandi of discrimination and exclusions perpetrated against nonconformist historical representations and imbricated in anti colonial nationalist narratives) by celebrating individual and communal performance of the national history. Aware of the fact that a large part of his Burgher's family trauma but also the whole nation's ordeal is the natural outgrowth of nationalists' outright failure to frame a new dynamic of identity beyond the sterile logic of binary oppositions inherited from the colonial discourse, Ondaatje seeks to free the national identity from the manacles of anticolonial nationalist history. While the latter seeks to impose a uni-dimensional perspective of the nation's past, Ondaatje autobiographical narratives celebrates the multiplicity of perspectives and transcends the merely informative dimension of the past and delves into its profound cultural significance.

Through the trope of family stories, folktales, and myths, the author moves away from the confines of the established political register of anti colonial struggle towards the wider cultural realms by reviving repressed representational symbols kept in collective popular memory. His portrayal of the nation is far from being a literary mimetic articulation of official narratives, but rather a highly self-reflexive narrative which is inextricably associated with the quest for origins. Ondaatje's desire to re-explore darkened stories of the past is motivated by his unflinching conviction that the crisis of Sri Lankan political discourse largely lies in its unthinking tendencies towards promoting historical amnesia. Aamir Mufti and Ella Shohat (1997) posit that "re-articulated notions of diaspora have played, notably, in the last decades, an important role in shaping national narratives that "not only charted the history of national communities displaced in post-independence era but also employed that history in the political criticism of nationalist discourse itself" (p.2). Along the lines of the new post-nationalist trend of diasporic writings, Ondaatje's memoir revolutionizes the historical narratives by introducing new representational modes such as blending myth and reality, and the communal with the national, which shift away from the classical totalizing ones that produce and perpetuate cultural marginality and political oppression.

In one of his interviews with Mark Witten, Ondaatje_as cited in Leon, 2010) confesses that "[he] love[s] that sense of history is not just one opinion". He rather "prefer[s] a complicated history where an event is seen through many eyes and emotions". He adds in the same context that: "[h]istory is not a dead thing, it is always alive"(p.94). In his autobiographical narratives, Ondaatje offers to the reader new perspectives of historical representations whereby he discovers new stories and new aspects of the Colonial and postcolonial Sri Lanka which were darkened in the time of nationalist hysteria and discarded in favour of ideologically loaded accounts of the past. These stories which are collected from popular memory and re-imagined by the author are mostly hovering around the daily lives of the marginalized Burgher community and mostly irrelevant with anti-colonial concerns. The events illustrated in Ondaatje's narratives of the past which are almost intimate, fragmented, and mystified flout the strict factual and scientific nature of historical writing. The characters which are cloaked in ambiguity withstand facile and reductionist colonizer /colonized identifications. Hence, they can never be easily situated within a welldefined political context

\section{CONCLUSION}

In Running in the Family, Michael Ondaatje suggests a different version of colonial and postcolonial Sri Lanka's biography through new guises whereby he sheds light on an obscured yet significant element of historical narrative, which is the fictional mythical one. The author's emphasis on the imagined rather than the factual with all its rich and open significations that reflect the diversity of national experiences and the depth of the cultural repertoire implies an obvious counter-hegemonic project that seeks to redefine the established boundaries of national history in nationalist historiography, and to disrupt pertaining notions of totality and closure. . Through fictionalizing the biography of colonial and postcolonial Sri Lanka, Ondaatje highlights alternative perspectives and illuminates more profound dimensions of the past which transgress the strict political confines prescriptively delineated by the mainstream ideology. His narrative carries an implicit critique of anti-colonial nationalism and its inherent dogmatic perception of national history by deconstructing its underlying the narrative paradigms of discursive hegemony, even when eschewing direct political involvement the anti-colonial agenda.

This problematized representation challenges the dominant reductionist and exclusionary official one. Communal memory (mainly of the burger community) which is the author's main source throughout the memoir offered a productive site of contestation through which not only alternative competing historical narratives emerge, 
but also competing representational paradigms, which potentially undermine the authority of the discursively established ones. The revisitation of historical narrative is one of the main strategies whereby a contentious biography of colonial and postcolonial Sri Lanka is drawn and celebrated in Ondaatje's memoir. Yet, it is not the only one. The re-exploration and the re-writing of cartographic and ethnographic narratives are among the principal means of Ondaatje's postcolonial and postmodern counternarration. This issue can be the object of a future study.

\section{REFERENCES}

[1] Bhabha, H. K. (1994). The Location of Culture. London: Routledge.

[2] Clarke, G. E. (1991). Michel Ondaatje and the Production of Myth. Studies in Canadian Literature, 16(1), np. Retrieved from https://journals.lib.unb.ca/index.php/SCL/article/view/8129

[3] Colavincenzo, M. (2003). Trading Magic for Fact, Fact for Magic: Myth and Mythologizing in Postmodern Canadian Historical Fiction. Amsterdam: Rodopi.

[4] Coleman, D. (1998) Masculine Migrations: Reading the Postcolonial Male in New Canadian Narratives. Toronto,TO: Toronto University Press.

[5] Dittmer, J. (2010) Popular Culture: Geopolitics, and Identity. London: Rowman \& Lettlefield.

[6] Haddad-Null, E. K.. (2013). "Family Stories: Narrating the Nation in Recent Postcolonial Novels" Doctoral Dissertations. 206. Stoors. Connecticut, CT: UConn. Retrieved

from https://opencommons.uconn.edu/dissertations/206

[7] Hartman, G. H. (1994). Public Memory and Its Discontents. Raritan, 13(4).24-40,

Retrieved

From http://connection.ebscohost.com/c/articles/9502081712/pub lic-memory-discontents.

[8] Kanaganyakam, C. (1992). A Trick with a Glass: Michael Ondaatje's South Asian Connection. Canadian literature, 13(2), 33-42. $\quad$ Retrieved from http://citeweb.info/19920213845.

[9] Klein, G. (1997). The Use of Myth in History. Colonial Williamsburg Journal,. $n p(\mathrm{np})$, 1-10. Retrieved from https://research.colonialwilliamsburg.org/Foundation/journ $\mathrm{al} /$ summer12/myths.cfm

[10] Leon, C. E. (2010). Understanding and Living Diaspora in Michael Ondaatje's Running in the Family and Amitav Ghosh's Shadow Lines. Sarjana, 25(2), 33-42.

Retrieved

from http://repository.um.edu.my/id/eprint/110366.

[11] Mufti, A, \& E Shobat, E .(1997). Introduction. In. A. McClintock, A. Mufti, \& E. Shobat (eds.), Dangerous Liaisons: Gender, Nation, and Postcolonial Perspectives (1-14). Minneapolis, Minnesota: Minnesota UP.

[12] Mukherjee, A. (1994). Oppositional Aesthetics: Readings from a Hyphenated Space. Toronto, TO: TSAR Publications.
[13] Ondaatje, M. (2011) .Running in the Family. Toronto: Vintage Canada Edition.

[14] Saul, J. .(2006). Writing the Roaming Subject: The Biotext in Canadian Literature. Toronto,TO: Toronto University Press.

[15] Seyhan, A. (2001). Writing Outside the Nation. Princeton, NJ: Princeton University Press.

[16] Tallack, D. (2013) Critical Theory: A Reader. London: Routledge.

[17] Tooher, D. (2010). Michael Ondaatje's Recreation of Identity in Running in the Family. Munich: Grin Verlag.

[18] Verhoeven, W,.M.(1992). (De) Facing. Michael Ondaatje and (Auto) Biography. In T. D’Haen \& H. Bertens (Eds.), Postmodern Fiction in Canada (181-200). Radopi.

[19] Wundt, W. (2006). Ethics: The Facts of Moral Life. New York, NY: Cosimo.

[20] Yow, V.R. (2005). Recording Oral History: A Guide for Humanities and Social Sciences. Rowman \& Littlefield. 